\title{
A relevant ministry for the armed forces: An agenda for the South African National Defence Force chaplains praxis
}

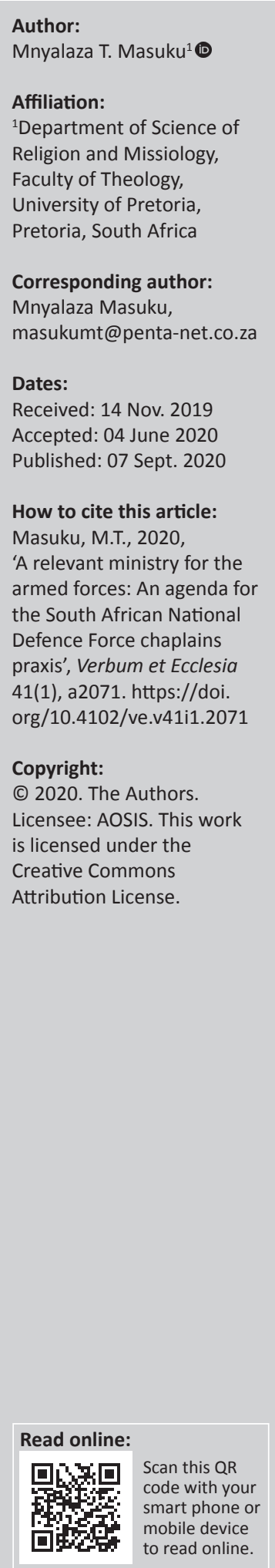

Chaplaincy in South Africa (SA) recently became an attractive ministry and research fields for both ministers and theologians, respectively, more especially since the dawn of democracy in 1994. The military chaplaincy has been flooded with applications and enquiries from ministers and leaders from religions other than Christianity who want to secure their space in the ministry to the SA armed forces. Individual churches are also joining the queue for enquiries. As SA is a multireligious nation, religions other than Christianity are also knocking at the door of the South African National Defence Force (SANDF), claiming their right to be accommodated. For this reason, it is important for churches, other religious organisations, leaders, ministers and theological institutions or faculties to have knowledge of this unique world and its context, as well as the ministry dynamics and challenges involved. This will assist them in order to prepare appropriately in terms of shaping the curricula and qualifications of their ministers for effective ministry to the armed forces with special reference to the SANDF. This article investigates the dynamics of the military chaplaincy in relation to historical developments along similar chaplaincies globally, the nature of its ministry to the SA armed forces and the challenges posed by the ministry context (SANDF environment), and finally, it crafts and proposes a suitable curriculum for a relevant and effective ministry in the SANDF and the world.

Intradisciplinary and/or interdisciplinary implications: This article is located in the field of Missiology. However, it has interdisciplinary implications that affect disciplines such as Military Science, Sociology, Practical Theology and Church History, which all assist as building blocks towards a relevant ministry for the armed forces.

Keywords: chaplaincy; armed forces; South African National Defence Force; ministry; ministers; chaplains; Department of Defence; theological education; curriculum.

\section{Introduction}

The armed forces are a very heterogeneous world with their own community of adherents to different religions. This community is made out of different minds such as medical doctors, police, legal practitioners, psychologists, fighters, social workers and so on. These professional categories, as in the South African National Defence Force (SANDF), demonstrate a clear representation in terms of gender, race and people with disabilities. Above all these, they collectively have ministers of religion, seconded by their churches to minister to them. Ministry in this dynamic scenario is of a special type, as it has to spiritually, socially and morally support all these individuals. For these reasons, a relevant theological formation based on a suitable curriculum is required to equip ministers who have been seconded to serve in this complex scenario.

The chaplaincy is a closed or unknown world for some, as has been observed by Mkhathini (2016:ix) with regard to the Department of Correctional Services in South Africa (SA), which is an observation that applies to chaplaincies in other organisations. Could what Bredenkamp and Wessels (2009:299) refer to as a scarcity of sources on military chaplaincy also be contributing to this concern? I refute this view on the grounds that these concerns point to a period in the late 1970s, and the situation has changed in recent years as scholars have started to research this field. The confidential nature of this organisation also makes it difficult for stakeholders like churches to have inner knowledge of its complexities in order to render a successful ministry. This was true from the view of Moll (1984) when he wrote:

$[I] \mathrm{f}$ it is true that the South African Chaplains' Service is changing at such a velocity that it is impossible for outsiders to have knowledge of the working of the organization, how does the Chaplain-General 
expect the churches to satisfy themselves that this is a valid form of ministry? (p. 18)

In light of this view, I am going to argue that the military chaplaincy is a valid form of ministry for churches and other religious organisations. Chaplaincy absorbs more ministers than other sectors that employ them, especially since 1994. I will, therefore, explore the meaning of the term 'chaplain' and what this vocation entails. Furthermore, I will outline the dynamics of the environment of the armed forces, the SANDF in particular, as well as challenges posed by this context towards a successful ministry. This will be followed by a proposal for what could be a relevant ministry curriculum for an effective chaplains' service with special focus on the SANDF as part of the global community of armed forces. In doing this, I will be joining Bredenkamp and Wessels (2012), who argued:

[I]t is important that the SANDF's activities should become part of a broader, informed public debate in South Africa; a debate that - ideally - should not be tainted by political considerations. (p. ii)

This should, however, be exercised within acceptable security lanes of the armed forces globally.

\section{Early beginnings of the military chaplaincy worldwide}

The term 'chaplain' originates from the Latin word capellanus. Bredenkamp and Wessels (2009:298) indicate that other scholars link this term to the relic cloak (capa) of St. Martin of Tours. This cloak was torn into two and shared with a shivering beggar. It was then guarded by a clergy (capellani) and taken to battle by the Frankish kings. A chaplain can, therefore, be defined as a member of the clergy or a priest ordained by his or her denomination to minister to a specific community in unusual circumstances, which may preclude normal church services, such as hospital, prison, police or military chaplaincy. Thus, Potgieter's definition as quoted by Moll (1984) is more appropriate for a military chaplain:

[A] member of the clergy of a particular denomination who is responsible for the spiritual care of members of the armed forces (and their dependants) both at the base and in the field. (p. 46)

During the Middle Ages, it was the responsibility of a chaplain to minister to those in the parish who lived inconveniently far from the parish church. It was basically meant to help people who had been taken away from their normal church environment and ministers.

There was a conflict between Christianity and war in the early years of Christianity. Those who participated in wars were regarded as sinners. Pacifism was highly encouraged. In the minds of Bredenkamp and Wessels (2009:301), this pacifism was grounded in the belief that by disarming Peter, Christ had taken the sword out of the hands of all Christians. As a result of this view, the Church of Alexandria did not accept soldiers as members. By the end of the 4th century, Christianity had become the official imperial religion, and it was incorporated into all structures of the empire. Viewpoints on pacifism changed, and some wars were justified.

Military chaplaincy developed according to the customs and traditions of different countries. By the 16th century, chaplaincy was firmly rooted in the British, French, Spanish and Dutch military traditions. Only after the establishment of the British Army in 1660 were the duties of chaplains specified (in 1662). I also noted the concept of a chaplain in traditional wars in Africa. For instance, during the Battle of Isandlwana on 22 January 1879, before they could go to war, the regiments needed spiritual power and support from traditional healers (izinyanga), whom I equate with what we call 'chaplains' today in terms of spiritual and moral support to armed forces within the space of African traditional religions (ATRs). The traditional healers were central in any battle, and without them no war was possible. Throughout the Anglo-Zulu War, beginning on Wednesday of 22 January 1879, the Zulu army enjoyed spiritual support (Laband \& Mathews 1992:7). The results of the spiritual support by the traditional 'chaplains' were well captured by Laband and Mathews (1992:20), who remarked about the Zulu army after the rituals: 'It was full of confidence and expected to finish off the British with ease'. I therefore find it difficult to agree with Bredenkamp and Wessels (2009:306) when they argued that 'the concept of military chaplain did not exist before the arrival of white people'.

Can chaplains also participate in combat during battles? The history of military chaplaincy is marked by instances in which they were allowed to participate in combat and also instances where they were not allowed to do so. For instance, Moll (1984:46) indicates that the Councils of Rome (402) and Tours (461) forbade chaplains from carrying arms. Bredenkamp and Wessels (2009:302) noted that the Council of Ratisbon (742) took a similar decision. When the Duke of Normandy invaded Britain in 1066, the chaplain fought with a mace because he was not allowed to carry arms. Another platform that forbade chaplains from fighting was the Synod of Westminster in 1175. This abstinence from fighting created a situation in which the clergy were bound by a higher set of moral values than others. However, a change to the non-combatant position for chaplains was seen at the end of the 11th century during the Crusades, when clergy participated in battles. Until the 17th century, the British military chaplaincy had what they called 'warrior priests'. However, from the 17th century on, chaplains' function was limited to the spiritual welfare of soldiers. At that time, the British colonies in North America still had fighting padres. They participated in skirmishes during the War of Independence in the 18th century. During World War II, military chaplaincy was structured in most countries, and this was propelled by a high number of prisoners of war (POWs) who needed their services. The rank and uniform for chaplains were standardised (Bredenkamp and Wessels 2009:304). The slogan of chaplains serving in the Allied Forces was well captured by Bredenkamp and Wessels (2009) as 'be there'.

The military chaplaincy as a formal institution in SA was established in 1914. Despite this, it was not recognised as an 
autonomous, integral part of the armed forces in SA until 1973. Bredenkamp and Wessels (2014:60-61) identified the cause for this delay in recognition as the friction between British imperialism and Afrikaner nationalism. These two forces had different viewpoints regarding ministry to armed forces, and there was generally animosity between them. The Afrikaners used civilian forces or commandos differently than the British, who had established armed force. The Afrikaners used local ministers to minister to the commandos. These ministers were also wearing two caps. Whilst they served as ministers, they were also used as combatants (Bredenkamp \& Wessels 2014:67).

At the outbreak of the Second World War (1939-1945), military chaplaincy was well structured in most countries. Greater mobility and the higher number of POWs influenced chaplaincy services. Bredenkamp and Wessels (2009:314) identified a singing SA Methodist chaplain, Rev. Ron Letcher, who inspired the POWs with his singing skills every evening at Tobruk in what was referred to as a 'hell camp' in Libya in 1942. The chaplains' role was expanded and an hour of instruction to the troops - known as the 'Padre's hour' - was introduced to boost the morale of soldiers. The aftermath of the Second World War brought a shift in emphasis from warrelated matters to ethical and moral concerns.

Ministry of chaplains has always been accompanied by controversy. Can they be prophetic in the same way as their civilian counterparts? Probably, the situation has changed today, because during the apartheid years there was noise against their ministry. Today, we speak of a peoples' SANDF. The question is how one can be prophetic in the military setup. It is a question of whether one is serving a just or unjust government. For instance, the South African Council of Churches (SACC) at its National Conference in 1984 adopted a statement in which, according to Moll (1984):

[I]t urged each member church to demilitarize their chaplains by relieving them of the symbols of military status like rank and uniform and to bring their chaplains under church authority, thereby releasing them from military influence. (p. 25)

Churches were faced with dilemmas regarding the ministry of chaplains during apartheid. That is why the Methodist Church of South Africa (MCSA), Presbyterian Church of South Africa (PCSA) and the Roman Catholic Church (RCC), in 1977 and 1988, attempted to renegotiate a new way of the services of their ministers seconded as chaplains in the apartheid regime. They attempted to restructure their ministers' ministry to military personnel in such a way that they would also minister to the freedom fighters (Moll 1984:24).

The question goes further within the space of ethics with regard to controversial operations or missions. For instance, Moll (1984) asked the apartheid South African Defence Force (SADF) if a chaplain was allowed to represent his or her church's view on ethical matters, especially to preach to the soldiers about the withdrawal of the SADF from the
then-South West Africa, currently Namibia. The response was well captured: 'It is expected from each chaplain to proclaim the Gospel of Jesus Christ and to take care of the spiritual needs of his church members, and nothing more' (Moll 1984). If one takes this into the democratic SA, what should the ministry have looked like of a South African Police Service (SAPS) chaplain to the police officers who were involved in the Marikana massacre on 16 August 2012, which former Minister Ronnie Kasrils (in Bell 2016:446) described as worse than the Sharpeville massacre in 1960? How should chaplains minister to the police and their thenCommissioner, Riah Phiyega, who after the massacre praised them: 'You guys did very well; you behaved as you should' (Chetty 2016:67)? What about the ambush and killing of 15 of the SANDF soldiers in the Central African Republic by 1000 Seleka rebels in May 2013, which Vrey and Esterhyse (2016:2) described as 'a military blunder rather than a logical outcome of policy informing military strategy in the pursuit of vital national interests'? How should a chaplain minister to the commanders, soldiers and their dependents under these circumstances?

In the light of this debate thus far, to a certain extent Bredenkamp and Wessels (2009) are correct in saying that:

$[M]$ inistry to armed units has been part of the history of humankind ever since the first military campaigns, but traditionally it did not include the concept of a religious person ministering to combatants in military circumstances. In most cases the ministry consisted of a priestly blessing ritual, entreating the holy one(s) for victory before the advance of the forces. Military chaplaincy is a modern concept that evolved in the Western Christian world. (p. 317)

Having looked at the early beginnings of the military chaplaincy worldwide, I will now narrow it down and look at the context of the SANDF in the following section. This exercise will indicate how the successes and the challenges of the global military chaplaincy over the years influenced the SANDF chaplaincy today.

\section{The context of the South African National Defence Force environment}

According to Esterhyse (2006):

[S]ince its inception the SANDF has focused almost exclusively on structural issues. These included the integration of pre-1994 belligerent forces into a cohesive defence force, the transformation of the military to reflect the democratic ethos of society, organizational restructuring to fit a declining defence budget and doctrinal changes to reflect South Africa's new role on the African continent. (p. 22)

The SANDF was born in 1994 as part of the democratic SA. Heineck and Van Der Waag-Cowling (2009:518; Bredenkamp \& Wessels 2012:242-243) point out that it was forged from a process which amalgamated different forces in SA. The focus of the SANDF has been peace on the continent of Africa, thus making Africa its theatre of operation. That is why Vrey and 
Esterhyse (2016:2) described the SANDF as a 'prominent vehicle or agency of South Africa's diplomacy towards Africa'. His views in this regard might have been built from the peacekeeping missions the SANDF is carrying out in many parts of the continent, as recorded by Van Nieuwkerk (2012).

Contrary to popular belief that armed forces are allergic to education, the SANDF underlined the need for education. Theletsane (2019) was correct when, in referring to the SANDF, he stated:

[T] oday's conflicts are more likely to be rooted in political, psychological, social and economic causes, than by merely military considerations. It therefore follows that military personnel should have a sound basic knowledge of a variety of disciplines that will enable military leaders and those under their command to think 'beyond the battlefield'. (p. 74)

Referring to this zeal for education, Esterhyse (2006) outlined it well when he stated:

[T] hey were needs that brought members of the different pre-1994 belligerent forces together in the classrooms of the newly created SANDF. It was primarily in the classrooms of the different training and educational institutions that most of the members of the pre1994 belligerent forces were introduced to each other for the first time. It was in these institutions that they were first confronted by their fears, where prejudices and old views were challenged and where a new team spirit was developed. (p. 28)

The SANDF also prepare their members for alternative careers on exit. For instance, Van't Wout and Van Dyk (2016:29) put it well: 'Members that have to exit the SANDF need career maturity to pursue alternative careers in the private sector'. Saayman (2013:134) indicates that the reason for existence of the University of South Africa (UNISA) was to serve the military community's interests. The aim was to serve soldiers after World War II, who were very old for fulltime tertiary education.

It is obvious that the constitution of SA requires SANDF members to have a higher understanding of their operating environment than that which is normally provided through training. The South African White Paper on Defence, under the heading 'Education and training', indicates that education and training are cardinal means of building and maintaining a high level of professionalism in the armed forces (Esterhyse 2006:25). The SANDF expects all officers to have at least a junior degree. Esterhyse (2006) outlined the study and training process in the SANDF well:

[A]fter one year of military training and socialization at the junior leader training institutions, the candidate officers are transferred to the Academy where the bulk of their time is taken up by academic (university) studies. Ideally, officers should graduate with a first degree and a commission as a lieutenant in a particular service after one year of training and three years of study. (p. 29)

The zeal for education amongst armed forces is not limited to the SANDF but is a universal phenomenon. Karsten (1998:x) alluded to this when he echoed that since World War II, the military has become more technologically sophisticated, employing more military specialists, and the trend has grown over the years. Think of the expression 'book soldiers!' (Karsten 1998:38) used within the Mexican army during the reign of General Porfirio Diaz that ended in the early part of the 20th century, referring to soldiers' association with education. General Omar N. Bradley (quoted by Guttieri 2006:235) was on point when he said, '[f] lor most ... the matter of learning is one of personal preference. But for military officers, the obligation to learn, to grow in their profession, is clearly a public duty'.

The aim of the Department of Defence (DOD) as the embodiment of the SANDF, according to the DOD Annual Report (2010/11:15), is to 'defend and protect the RSA, its territorial integrity and its people, in accordance with the Constitution and the principles of international law regulating the use of force'. The vision of the DOD is '[e]ffective defence for a democratic SA' (DOD Annual Report, 2018/18:12; DOD Annual Performance Plan 2018). The mission is:

$[T]$ o provide, manage, prepare and employ Defence capabilities commensurate with the needs of SA as regulated by the Constitution, national legislation, parliamentary and executive direction. The latter will be provided through the proper management, provision, preparedness and employment of Defence capabilities, which are in line with the domestic and global needs of SA. (p. 1)

This aim, vision and mission indicate that SA adopted what Jordaan and Esterhyse (2004:63) call a 'non-offensive defence (NOD)' approach for the SANDF. This was also emphasised in a document by the ruling party, the African National Congress (ANC), called 'Ready to Govern'. This position showed itself in the interim constitution of 1993 and was also adopted after 1994 by the democratic government. Along these lines, the SANDF also subscribed to what Esterhyse (2006:22) calls 'civil-military relations'. What does this imply? Is this a balance of power between the two? Guttieri (2006) comes to our rescue. He describes this as '[c]ivilian control, military subordination to civilian political rule'. He further reasons it out:

[T]wo primary indicators of democratic civilian control of the armed forces are, first, that an elected civilian official is commander in chief of the armed forces and second, that military officers abstain from political activity. This separation also makes it imperative that civilians develop the expertise to manage defence issues, oversee military competence, and ensure obedience. (p. 236)

This is clearly visible within the SA government system, in which the president is the commander-in-chief of the armed forces. Within the DOD there are two director-generals, one for the armed forces called chief of the SANDF and another one for the civilian component called the secretary for defence.

Some of the highlights of the SANDF programmes of action according to the DOD Annual Report (2010:14) include: force 
employment, landward defence, air defence, maritime defence, military health support and defence intelligence. A senior chaplain wearing the military rank of colonel or captain (the latter if in the navy), supported by a team of chaplains under his or her command, are responsible for ministry in each programme.

The aforementioned context of the SANDF enabled one to determine and understand how the chaplaincy fits into this military environment. The following section addresses the nature and dynamics of the Chaplain Service in the SANDF. It will demonstrate the challenges that have shaped the ministry of the chaplains in this context.

\section{The nature and dynamics of the Chaplain Service in the South African National Defence Force}

The birth of the SANDF in 1994 brought with it its own chaplaincy. This chaplaincy comprises about 160 fulltime chaplains fully representative in terms of race, gender and people with disabilities. In addition, there are about 250 reserves or part-time chaplains. These chaplains are to minister to an average number of 75051 (DefenceWeb 2018) members of the SANDF and their dependants. It is the biggest military chaplaincy in Africa. The chaplains are from the aforementioned amalgamated forces, churches and other religions such as Islam and Hinduism and bring a wealth of experience from their environments. Compare this figure with Britain, which had 280, and the United States (US), which had 1400 chaplains in 2008 (Bredenkamp \& Wessels 2009:306). During World War 1, SA had 150 full-time and 41 parttime chaplains (Bredenkamp \& Wessels 2009:311). The chaplaincy is an embedded activity in the SANDF. The end state is to have a ratio of 1 chaplain to 500 members, which is the size of a military unit. They deploy with their units at sea and on land.

The ministry of SA chaplains was similar to that of most chaplains of the Allied forces, which included parades, hospital visits, personal talks, distribution of parcels and literature and the writing of letters. The slogan of chaplains serving in the Allied forces during World War II - 'be there' (Bredenkamp \& Wessels 2009:304) - is accommodated in the SANDF chaplaincy in the form of ministry by presence (Religious Policy 2009:13). The 'padre's hour' is called a 'chaplain's period' in the SANDF. The characteristics of a chaplain are well captured in the DOD Religious Policy (2009):

[C]alled to minister in SANDF, helper on religious, social and moral needs, adaptable within the military environment, has a presence ministry, leads by example, minister to all interdenominationally, inspired trust and new hope facilitator. (p. 13)

The very religious policy further states that ' $[c]$ haplains provide a holistic and an all-encompassing religious ministry that includes ministry by word, counseling, care ministry by presence etc.' (DOD Religious Policy 2009:5). Religious support is an embedded activity in all the core processes of the DOD.

At some stage, SANDF deployed to 14 countries, and ministry by chaplains during those deployments is well captured by Bredenkamp and Wessels (2012):

[M]inistry was similar to that in the DRC. In keeping with the viewpoint that socio-economic matters should receive priority in Africa, SANDF involvement in the regions where they were stationed consisted of social support and feeding services to the local population, especially to street children and orphans. Chaplains also visited local churches, and good relations were maintained with the local church ministers. In Bujumbura, Burundi, South African troops donated money for the building of a church hall. (p. 258)

The vision of the Chaplain Service is: 'The DOD comprises people who are spiritually, ethically, and socially empowered' (DOD Religious Policy 2009). The mission of the Chaplain Service as a means of realising this vision is:

[T]he Chaplain Service, representing a cross-section of the religious communities in SA provides spiritual leadership to DOD members (at home and on deployment) in order to build human capacity that enhances spiritual, ethical and human wholeness. It does so within the context of religious diversity, taking cognisance of the transformation imperatives of the DOD and in support of democratic peace-building in Africa. (p. 12)

Highlights of the key performance areas included: a holistic approach to members of the SANDF and their families, specialists in religious and ethical counsel to all SANDF members, deployment readiness and resilience, a sound covenantal relationship and good communication with religious bodies to which chaplains belong, chaplains selfcare and development, special attention to urgent, social and ethical challenges in our contemporary society (SANDF 2018). In all of this, the principles of ministry apply: ministry by Word, pastoral care, presence and administration (SANDF 2018).

The aforementioned academic qualifications for chaplains bring them into alignment with that which was adopted by the SANDF for their military officers. They also enable them to provide quality spiritual, ethical and moral support to members of the SANDF and their dependants. For instance, during the weekly 40-min chaplain's period, chaplains are expected to motivate soldiers by addressing topical issues that affect military practitioners and their contexts. Thorough research and high-quality products are expected from the chaplains. This is possible through proper training and research capabilities.

Having looked at the dynamics and context of the global military and the SANDF in particular, as well as the development of military chaplaincies over the years, the following section proposes a relevant curriculum for the aforementioned military environment. 


\section{Towards a relevant curriculum for effective ministry in the South African National Defence Force}

Having been introduced to the dynamics of the SANDF, as well as the type and approaches of chaplain support, what type of theological formation and skills could provide excellent and relevant service in this unique scenario? In my quest to construct a relevant curriculum for effective ministry to SA armed forces, I fore-grounded Africa and Southern Africa in particular. Placing Africa at the periphery is the cause of the whole problem we are faced with today. As such, I placed Africa at the centre, not centring Europe in Africa as a European outpost in terms of the theological education curriculum. This was not completely avoided, however, because a curriculum (though decolonised) should be in dialogue or contestation with global spaces, including the Global North. In the process, I also accepted that I would be influenced by two approaches to curriculum theory and practices: curriculum as context and curriculum as praxis.

Theological education has always attracted critics. That is why in their discussion of what they themed ' $t$ the problematic of Theological Education', Hough and Cobb (1985:1) disclosed that there is a widespread discontent with theological education for ministers in the 'mainline' Protestant churches in the United States of America. They argued that the curricula of schools are too academic and have little relevance for the actual practice of the ministry. Neuhaus (1992:vii) also contributed to this debate by putting theological education parallel to moral formation and looking at the relationship between these two, or rather the confusion this may bring in other circles.

The determination of relevant theological subjects and what their contents should be forms another question. Can one consider the inclusion in the curriculum of what Qgubule (in Richardson 2007:135) calls 'general education', meaning academic and non-theological subjects? How should context be addressed? Should one follow the line of Theron's (1993:80) thinking, who reasoned that theological education should accommodate the different contexts in which it finds itself? Both Qgubule's and Theron's suggestions are very important in this regard. Of similar importance are the views presented by two scholars. Maluleke (1994:10) suggested the adoption of a specific theological framework but at the same time warned that the framework stands a risk of being betrayed by the demarcation of fields and subjects. Cochrane (1996:4) pleaded for the following areas to be considered for addition into the theological curriculum: gender, racism, leadership role of the church in society, the changed nature of leadership and culture.

The current qualification requirements for chaplains in the SANDF are stated in the DOD religious policy (2009:14): 'The minimum qualification needed for appointment as a Chaplain is Grade 12, a degree in theology or NQF level 7 equivalent and a letter of ordination/equivalent'. The SANDF's approach to education and further studies moved from the premise stated in the DOD Religious Policy (2009):

$[K]$ nowledge is the fundamental ingredient for dynamic competitiveness. The way for the chaplains to expand their knowledge is through appropriate education, training and skills upgrading. Most chaplains have functional knowledge that can and should be enriched. Chaplains who do not have sufficient functional skills will be given the opportunity, subject to availability of funds and within Departmental regulations, to develop those skills. (p. 20)

The training of chaplains was done in different ways to meet the challenges posed by their ministry context. Bredenkamp and Wessels (2012:264) indicate that the trauma counselling course was organised with UNISA in 2008. This course enabled chaplains to deal with trauma situations. Chaplains were also enrolled at North West University, Potchefstroom Campus, for a course in preserving life stories. The focus of this course was on the spiritual and emotional processes conducive to healing in society. Chaplains were also trained to face combat situations but still to function as 'hope givers' under these circumstances. Above all, a Master of Philosophy programme was also successfully negotiated with the University of Stellenbosch, in which chaplains were enrolled.

This unique military context requires chaplains with a minimum of a Master's degree. This requirement springs from the fact that the SANDF is undergoing a project to ensure that all officers possess at least a junior degree within a particular time frame. Relevant disciplines for effective ministry to these armed forces are therefore:

- Theological Ethics: This will empower chaplains to make sound and informed decisions within the challenging situations of their work context.

- Comparative Study of Religions: Chaplains minister in context with adherents of many religions. Although the most prominent religions in the SANDF are Christianity, Islam and Hinduism, there are other religions in the background such as African traditional religions and others. There are even those who possess a lack of belief in gods (so-called atheists) who also expect moral support from chaplains.

- Ecumenism: The interdenominational background of the chaplains and most soldiers requires chaplains to be armed with knowledge of the dynamics of ecumenism.

- Chaplaincy Studies: A course in Chaplaincy Studies will also make a huge difference in arming ministers for excellent service as chaplains to armed forces.

- Military Science: The inclusion of a course in Military Science will make a meaningful difference in chaplains' understanding of the military environment and culture. It will familiarise chaplains with the dynamics of the military world. This will enable them to produce relevant and value-adding ministry in the context of the armed forces.

- Mission Studies: Studies in this field will also be a necessity. This is because it will expose chaplains to the different contexts in which they will have to minister, which includes exploring different cultures, traditions and belief systems. 
- English: The study and knowledge of English language is a requirement. This language is currently used in SA for general communication in business, education and society. The inclusion of English in ministry formation for prospective chaplains will be helpful for effective ministry in the SANDF or other military formations worldwide. This will also be important because military training and academic programmes are conducted in English in the SANDF.

- African Languages (of SA): Because the SANDF is a microcosm of SA society, which has 11 official languages, it is important for those being prepared for ministry in the chaplaincy to have understanding and knowledge of as many languages as possible. With this language scenario, one can recommend knowledge and competency in at least three African languages.

- Swahili: The knowledge of Swahili will be an added advantage as a lingua franca of the African Great Lakes region, where the SANDF traditionally deploys.

- French: Because most SANDF deployments are in Francophone countries on the African continent, competence in French will make a positive difference.

These courses will equip chaplains for the military context and enable them to produce value-adding ministry in the SANDF and other armed forces. They could be done either on a diploma or degree level at colleges or universities. Ministers who are seconded by their churches with this academic background will lessen the necessity for additional in-service training whilst in the service of the armed forces.

\section{Conclusion}

Other developed nations with long histories of military chaplaincies have special chaplaincy institutions of higher learning. Some of them are even at the level of universities. The United States stands out as an example. They have a chaplains' school at Fort Jackson, Columbia, in South Carolina. These types of specialised institutions are in a position to sharpen the curricula for chaplains and make their ministry to their armed forces more relevant and effective. South Africa will need such initiatives in order to have relevant, contextual and 'prophetic' ministry within her armed forces.

The SANDF chaplaincy is currently negotiating with local universities and military colleges within the DOD for space to train their chaplains. Their current learning programmes are attracting and attended by chaplains even beyond SA. Churches are also to be encouraged to accommodate military chaplaincy-related matters in their ministerial formation programmes or curricula.

Religious communities also need to arm themselves appropriately in the light of the guidelines outlined in this article. Their efforts in this regard will prepare and enable them to second properly qualified ministers to serve in the armed forces.

\section{Acknowledgements Competing interests}

The author declares that no competing interests exist.

\section{Author's contributions}

I declare that I am the sole author of this research article.

\section{Ethical consideration}

The author declares that ethical clearance was not required for the study.

\section{Funding information}

This research received no specific grant from any funding agency in the public, commercial or not-for-profit sectors.

\section{Data availability statement}

Data sharing is not applicable to this article as no new data were created or analysed in this study.

\section{Disclaimer}

The views and opinions expressed in this article are those of the authors and do not necessarily reflect the official policy or position of any affiliated agency of the authors.

\section{References}

Bell, T., 2016, The Marikana Massacre: Why heads must roll? New Solutions, A Journa of Environmental and Occupational Health Policy 25(4), 440-450. https://doi. org/10.1177/1048291115621085

Bredenkamp, I. \& Wessels, A., 2009, 'The development of the Military Chaplaincy with special reference to SA', Journal for Contemporary History 43(1), 298-317.

Bredenkamp, I. \& Wessels, A., 2012, 'A historical perspective on Military Chaplaincy Services in the South African National Defence Force 1998-2012', Journal for Contemporary History 37(2), 242-267.

Bredenkamp, I. \& Wessels, A., 2014, 'The early history of South African military chaplaincy: A case study of the variance between British imperialism and Afrikaner nationalism, c.1914-1973', Journal for Contemporary History 39(2), 60-80.

Chetty, R., 2016, 'The Marikana Massacre: Insurgency and counter-insurgency in South Africa', New Forum 25(2), 62-70. https://doi.org/10.1177/1095796016639296

Cochrane, J.R., 1996, 'The contextualisation of theological education', Bulletin of Contextual Theology 3(3), 1-9.

DefenceWeb (2018, November 30), SANDF by numbers, viewed 15 October 2019, from https://www.defenceweb.co.za/.

Department of Defence (DOD), 2009, Religious Policy of the Department of Defence, 2009 edition (July).

Department of Defence (DOD), 2010, Department of Defence Annual Report (South Africa), Safeguarding South Africa for a better life for all. 01 April 2010 to 31 March 2011.

Department of Defence (DOD), 2018, Department of Defence Annual Performance Plan, 2018, Department of Defence, Government Printers, South Africa.

Esterhyse, A., 2006, 'Educating for professionalism: A new military for a new SA', Scientia Militaria, South African Journal for Military Studies 34(2), 21-43. https:// doi.org/10.5787/34-2-22

Guttieri, K., 2006, 'Professional military education in democracies', in T.C. Bruneau \& S. Tollefson (eds.), Who guards the guardians and how. Democratic civil-military relations, pp. 235-262, University of Texas Press, Austin.

Heineck, L. \& Van Der Waag-Cowling, N., 2009, 'The politics of race and gender in the SA Armed forces: Issues challenged and lessons', Common Wealth and Comparative Politics 47(4), 517-538. https://doi.org/10.1080/14662040903375414

Hough, C., Jr. \& Cobb, J.B., Jr., 1985, Christian identity and theological education, Scholars Press, Atlanta, GA.

Jordaan, E. \& Esterhyse, A., 2004, 'South African Defence since 1994. The influence of non-offensive defence', Defence Security Review 13(1), 59-69. https://doi.org/10. 1080/10246029.2004.9627271 
Karsten, P., 1998, The military and society. Training and socializing of military personnel. A collection of essays, A Garland Series, New York, NY.

Laband, J. \& Mathews, J., 1992, Isand/wana, Centaur Publications, Pietermaritzburg.

Maluleke, T.S., 1994, 'Restructuring theological education in South Africa', Unpublished Paper read at the annual General meeting of the Institute for Contextual Theology (ICT), 21 June, Braamfontein.

Mkhathini, M.M., 2016, 'A critical analysis of the Chaplaincy in the South African Correctional services from 1994', Doctoral thesis, Department of Practical Theology, University of Pretoria, Pretoria.

Moll, P.G., 1984, 'A theological critique of the military chaplaincy of the English-speaking churches', M.A. Dissertation, University of Cape Town, Cape Town.

Neuhaus, R.J., 1992, Theological education and moral formation, Encounter Series 15 Eerdman's Publishing, Grand Rapids, MI.

Richardson, N., 2007, 'Ministerial training and theological education in the Methodist Church of Southern Africa: The road ahead', Missionalia 35(2), 131-152.
Theletsane, K.I., 2019, 'The form and content of the ethics programme in the South African National Defence Force', African Journal of Public Affairs 11(1), 74-92.

Theron, P.F., 1993, 'Theological training in the context of Africa: A Freirian model for social Transformation as part of the missionary calling of the church', DTh-Thesis, University of Pretoria, Pretoria.

Saayman, W., 2013, 'Mission as theological education: Is Christian mission history coming full circle', Missionalia 40(3), 133-145.

South African National Defence Force (SANDF), M. Pillay (ed), THE MILITARY CHAPLAIN, South African National Defence Force (SANDF), 2018, 18(1), n.p.

Van Nieuwkerk, A., 2012, 'South Africa and peacekeeping in Africa', African Security 5(1), 44-62. https://doi.org/10.1080/19392206.2012.653307

Van't Wout, G. \& Van Dyk, G., 2016, 'Factors influencing career maturity in the SANDF. A diagnostic approach', Journal of Psychology in Africa 26(1), 29-34. https://doi. org/10.1080/14330237.2016.1149334

Vrey, F. \& Esterhyse, A., 2016, 'South Africa and the search of strategic effect in the Central African Republic', Scientia Militaria, South African Journal for Military Studies 44(2), 1-27. https://doi.org/10.5787/44-2-1174 